\title{
European Union Financial Support for Rural Development: Infringements Identification Problems in Lithuania
}

\author{
Dalia Averkienè \\ Department of Law, Faculty of Business Management, Vilnius Gediminas University, Vilnius, Lithuania \\ E-mail:dalia.averkiene@vgtu.lt
}

Received 13 February 2017; accepted 07 April 2017

\begin{abstract}
Funds allocated in accordance with various instruments of the Lithuanian rural development programme to businesses must help to achieve agriculture policy goals. During the implementation of financial support from the European Union, beneficiaries commit infringements and, consequently, support that was given to them or a part thereof may be withdrawn. Research results show that infringement research and the assessment of documents, which influences the making of decisions on the payment of financial support, must not only be adequate, but also efficient in order to protect public and private interests. Excessively long assessment of documents and investigation of suspected infringements may cause damage to beneficiaries, particularly if the beneficiaries did not commit infringements. On the other hand, inadequate and untimely assessment of documents may cause damage to the national budget and the European Union budget when support that is paid to persons who have committed infringements is misused and the objectives of granted support are not achieved. Therefore, adequate and efficient investigation of infringements is an important part of implementing financial support from the European Union for rural development.
\end{abstract}

Keywords: infringement, identification, financial support, legal regulation, timely, damage.

JEL Classification: K22, K29.

Conference topic: Modern Business Management Problems and Perspectives.

\section{Introduction}

The common agricultural policy is one of the policy areas of the European Union (hereinafter - EU) aimed at increasing efficiency of agricultural production, promoting technical advancement, ensuring reasonable development of agricultural production, improving living conditions of farming population, stabilizing markets, guaranteeing sufficient supply, and ensuring affordable prices for consumers. In addition to these specific aims of the agricultural policy, the EU Parliament agreed to incorporate new goals into the common agricultural policy the achievement of which would facilitate in addressing new challenges: ensuring decent quality of products, public health, sustainable development, economic and social cohesion, environmental protection, tackling of climate change (Massot 2016). Upon the EU accession of the Republic of Lithuania in May 2004, Lithuania, inter alia, committed to contribute to rural development by creating the necessary legal conditions, to provide funding, ensure the implementation of financial support allocated for that purpose, control the proper utilisation of funds of the European Union and national budget for this purpose, take measures to avoid damage to the European Union and national budgets.

The EU policy covers different areas which were analysed in the doctrine of science from different aspects. For instance, the EU integration and cohesion was explored by other scientists who have spoken on them in other sources (e.g., Lobanova 2015; Melnikas 2012a, 2012b, 2012c; Wiener, Diez 2009; Taran et al. 2010; Rakauskienè, Ivashinenko 2011; Potluka et al. 2010; Muiznieks et al. 2013; Van Well 2012; Panorama 2013; Exploratory Opinion of the European Economic and Social Committee 2011). The issues of the EU financial support were also analysed from different aspects by other scientists (e.g., Jakaitiené, Klyvienè 2007; Damulienè 2012; Palšova et al. 2014; Carlier et al. 2010). The issue of the impact of the EU financial support on rural development was also investigated in the doctrine of science (Baležentis, A., Baležentis, T. 2010; Vaznonis, V., Vaznonis, B. 2011). Still, differently from other sources, this article will deal with one of the aspects of the EU financial support for rural development - the problems of the identification of infringements in the implementation of allocated support. 
In implementing the EU financial support for rural development it is necessary to ensure its effective use and application. Authorities administering the EU support, acting in compliance with certain rules (Rules for the Administration of the Lithuanian Rural Development Programme 2007-2013, 2007 (hereinafter - the Administration Rules 2007); the Rules for the Administration of the Lithuanian Rural Development Programme 2014-2020, 2014 (hereinafter - the Administration Rules 2014) receive and evaluate applications, the applications which meet the eligibility criteria are accepted, support agreements are signed, payment claims are received and examined. Having identified any infringements, support is refused. Projects implemented using the EU support funds are examined over the period established by legal acts ( 5 or 7 years). The authority administering support having identified infringements which have not been remedied by the beneficiary over the specified time limit must impose sanctions, i.e. recover a part or all disbursed amount of support from recipients of support (mainly business entities). The proper and effective identification of infringements are decisive for the entities' finances and further operations as well as for the proper use of the EU and national budget funds, i.e. the use of the funds according to their purpose, the achievement of the goals of support, avoiding damage to the EU and national budgets. If infringements are identified improperly, damage can be made both to the beneficiaries (business entities) and the State, as well as to the European Union budget. Protracted investigation into alleged infringements can negatively affect further implementation of the projects of beneficiaries (and business entities), when, for example, after delayed disbursement of funds beneficiaries have to implement the project over the remaining short terms. On the other hand, in order to investigate the infringement, all facts must be examined and evidence must be collected conducting on-site checks, etc. Therefore, the main problem raised in the article is how to ensure the correct and effective identification of infringements which leads to consequences in respect of both business entities and the State and the European Union budget.

Investigation purpose: to raise regulatory and practical problems of the identification of infringements related to the financial support for rural development.

To achieve this purpose the following targets are set:

1. To disclose the concept of infringement in terms of financial support for rural development;

2. To raise the regulatory problems in the identification of infringements;

3. To identify certain practical problems in the identification of infringements.

To achieve the aim of the article, used the following approaches: systematic and logical analysis, generalization, analysis of documents, qualitative content analysis, empirical data collection and systematisation.

Used sources: scientific articles, dissertations, national and EU legislation, empirical data of identified infringements.

\section{Concept of infringement in terms of financial support for rural development}

For the purpose of analysing the problems of identification of infringements, in the first instance, it is expedient to disclose the concept of infringement in terms of financial support for rural development.

In the doctrine of science, the infringement, as a rule, is considered to be a guilty act which contradicts the law and causes damage to the individuals' rights and legitimate interests protected by law, legal arrangements in general, and which is linked to the imposition of sanctions (Vaišvila 2004; Kelsen 2002). The scientists who investigated the EU law and its implementation in the EU Member States (Thomson et al. 2007) consider that an infringement exists when requirements of the EU legislation (e.g., directives) are not complied with. In the positive law, the infringement in terms of financial support for rural development is any infringement of a provision of Community law resulting from an act or omission by an economic operator which has, or would have, the effect of prejudicing the general budget of the Communities either by reducing or losing revenue accruing from own resources collected directly on behalf of the Communities, or by charging an unjustified item of expenditure to the Community budget (Commission Regulation (EC) No 1848/2006 of 14 December 2006). The national positive law defines the infringement of provisions of legal acts (hereinafter also - infringement) as an act or omission by an applicant or a beneficiary disregarding provisions of legal acts of the European Union and/or Lithuanian which has, or would have, the effect of prejudicing the general budget of the Communities and/or the State Budget of the Republic of Lithuania (the Administration Rules 2007; the Administration Rules 2014). Such definition of the infringement is logical and corresponds to the general concept of infringement. Still, the question arises about the relationship between the identification of the infringement and time limits? As a rule, sanctions are imposed for the infringement, but is it always possible to impose sanctions for the infringement? Therefore, in disclosing the concept of the infringement related to the proper and effective use of support for rural development it is expedient to analyse the relationship between the infringement for which a sanction is imposed and the time limits.

As already mentioned, the infringement is linked to sanctions as a means of rectifying the inflicted damage. When allocating and implementing the EU financial support for rural development the control period for support projects is set during which it is examined how the project is being implemented, whether there are any deviations from the project, whether its purpose has not been changed and investments acquired for the support funds have not been transferred. The period of five or seven years is set from the day of signing the support agreement or adoption of the decision on the granting of support during which it is examined how the beneficiary fulfils the obligations provided 
for in the project and/or support agreement (the Administration Rules 2007). An essentially similar provision is established in the rules for the new period (the Administration Rules 2014). Thus, sanctions for committed infringements related to the allocation of financial support for rural development are applied only for a certain period, i.e. 5 or 7 years (in the new period, the term of 5 years from the last payment of support is established). The entity carrying out supervision during the project control period, i.e. the National Paying Agency under the Ministry of Agriculture (hereinafter - NPA) can and must carry out the project supervision and impose sanctions in the case of infringements. During the project control period defined by legal acts the beneficiary must fulfil the obligations assumed under the support agreement, implement the project properly and submit reports and information to the entity administering support only over a certain period, i.e. 5 or 7 years. This means that a certain act or omission may be regarded as an infringement only when it occurs during the project control period.

Legal acts stipulate that after expiry of the supervision period, the beneficiary must submit a final report. The question arises - can the project be examined and sanctions imposed during a certain period when the project control period has already expired? Legal acts establish the obligation for a beneficiary to submit to the NPA the annual report on the completed project within 4 months of the end of each calendar year (the Administration Rules 2007: 187; the Administration Rules 2014: 170.2). The report shall also be submitted for the last year of implementation of the project, i.e. for the last year of the project control period when the project had to be properly implemented. Furthermore, legal acts allow evaluating the annual report on the completed project in accordance with the procedure established by the NPA until 31 October of the current year (the Administration Rules 2007: 188; the Administration Rules 2014: 169). If at the end of the control period the project is not examined, infringements might occur during the last year. The failure to identify the infringements and to impose sanctions for them could lead to ineffective consumption of support funds and damage to the EU and/or national budget. The non-examination of the report and non-imposition of sanctions for activities funded with support funds carried out during the last year would not ensure the effective and proper use of support funds. Therefore, even after expiry of the project control period, the proper implementation of the project should be examined for the last year until 31 October of the current year and upon identification of any infringements sanctions should be imposed.

Therefore, the infringement in terms of financial support for rural development can be defined as an act or omission by an applicant or a beneficiary disregarding provisions of legal acts of the European Union and/or Lithuania which has, or would have, the effect of prejudicing the general budget of the Communities and/or the State Budget of the Republic of Lithuania, for which sanctions are imposed if the infringement is committed during the project control period.

\section{Relevance of the proper and effective identification of infringements}

The significance and relevance of identification of infringements is also reflected by the fact that the EU and national budget funds to beneficiaries (business entities, farmers) for rural development are approved and paid each year under different measures of the Lithuanian Rural Development Programme (e.g., support for cooperation of small economic entities; support for promotion of short supply chains and local markets at local level; compensatory payments per hectare of agricultural land in other areas facing natural constraints). The table below shows the amounts of allocated and paid out funds.

Table 1. Data on funds approved and paid out for the implementation of the Lithuanian Rural Development Programme 2014-2020 (Source: The Table was drawn up by the author summarising the data provided by the NPA (statistics of the implementation of the Lithuanian Rural Development Programme for 2014-2020)

\begin{tabular}{l|c|c|c}
\hline \multicolumn{1}{c|}{ Year } & 2014 & 2015 & 2016 \\
\hline $\begin{array}{l}\text { Approved applications, } \\
\text { signed agreements }\end{array}$ & 72107 & 106754 & 63416 \\
\hline Approved amount of support, EUR & 115457672 & 474407272 & 250688738 \\
\hline Paid amount of support, EUR & 893639 & 112818656 & 118534324 \\
\hline
\end{tabular}

The data presented in the table show that the allocated and approved amounts of support usually are larger than paid amounts. Upon allocation of funds according to investment measures, the amount of support is paid when it is established that investments were made properly (e.g., the proper machinery was acquired, buildings for the implementation of the project activities were constructed in a proper and timely manner, etc.) and within the established time limits. Due to that it is important to properly and effectively assess the submitted payment claims (to decide according to the submitted payment claims whether investments were implemented), determine whether any infringements were committed due to which the support should not be paid out. Only having ascertained that there are no infringements, the amount of support can be paid out to the beneficiary. Having identified any infringements, the amount of support or its part is not paid out. Sanctions - recovery of all or part of the amount of support - can also be applied for infringements identified when carrying out the project supervision during the project control period. The 
earlier the infringements are identified, the more effective application of sanctions and the avoidance of damage to the EU and/or national budgets can be. Due to these circumstances the proper and effective (timely) identification of the infringement is significant for the proper implementation of the EU financial support and achievement of goals of the financial support for rural development.

Upon submission of data on payment of support funds for rural development it is expedient to provide the data on the quantity of identified infringements, the amounts to be recovered or not allocated due to identified infringements. To that end, using the empirical study the analysis of infringements received and investigated by the Ministry of Agriculture of the Republic of Lithuania in 2015 and 2016 in the case of which the amount of sanction exceeds EUR 28962.00 was carried out. Given that the infringements for which the proposed amount of sanction is smaller than EUR 28962.00 are investigated by the NPA, the total quantity of infringements investigated in Lithuania as well as the total amount of sanctions is larger. Infringements are investigated in observance of paragraph 10 of the Rules for the Administration of Violations of Legislative Provisions, 2010. According to the amendment to the aforementioned Rules which entered into force on 15 December 2016, infringements will be investigated by the Ministry of Agriculture when the amount of proposed sanction is larger than EUR 50000 (Amendment to Order No 3D-80 of the Minister of Agriculture of 5 February 2010, 2016).

Table 2. Types and quantity of investigated infringements and amounts of imposed sanctions (Source: The Table was drawn up by the author having analysed the data of examined infringements)

\begin{tabular}{l|c|c|c|c}
\hline \multicolumn{1}{c|}{ Year } & \multicolumn{2}{c|}{2015} & \multicolumn{2}{c}{2016} \\
\hline Types of infringements & $\begin{array}{c}\text { Quantity of } \\
\text { Infringements } \\
\text { (units) }\end{array}$ & $\begin{array}{c}\text { Total amount } \\
\text { of sanction, } \\
\text { EUR }\end{array}$ & $\begin{array}{c}\text { Quantity of } \\
\text { Infringements } \\
\text { (units) }\end{array}$ & $\begin{array}{c}\text { Total amount } \\
\text { of sanction, } \\
\text { EUR }\end{array}$ \\
\hline Infringements of public procurement & 8 & 590527.21 & 1 & 70000 \\
\hline Creation of artificial conditions for obtaining support & 5 & 2072227.5 & 10 & 1288978.06 \\
\hline Non-performance of activities & 37 & 11569459.98 & 20 & 4646503.83 \\
\hline Increased prices & 19 & 1214706.7 & - & - \\
\hline $\begin{array}{l}\text { Other infringements (not achieved indicators, not } \\
\text { unimplemented projects, not obtained permits, etc.) }\end{array}$ & 30 & 3112442.29 & 5 & 310452.11 \\
\hline
\end{tabular}

The data presented in the table above reflect sanctions proposed for committed infringements, i.e. seeking to recover paid out, but incorrectly used funds or their part. Sanctions are also imposed, i.e. support or its part is not paid out when conditions for receiving support are not met, and e.g., payment claims are not submitted, equipment is purchased at higher prices, etc. Infringements are investigated in order to ensure the proper consumption of financial support. This shows that the identification of infringements is a relevant and important process of administration and control of the EU financial support for rural development during which violations of legal acts are disclosed, sanctions are imposed (recovery of support or its part) aimed at ensuring proper implementation of funds of the EU and national budgets so as to avoid damage to the EU and national budgets. Having regard to the significance of identification infringements, it is expedient to name certain regulatory and practical problems in the identification of infringements.

\section{Regulatory problems of the identification of infringements}

Legal regulation necessary for ensuring the proper and effective identification of infringements must create legal preconditions for guaranteeing the identification of infringements and imposition of sanctions for them so as to avoid damage to the EU and national budgets without violating the rights of beneficiaries. Due to the limited scope of the article, several problems of legal regulation will be discussed.

One of more complicated infringements in both the identification and financial terms (when the aim is to obtain by several times larger support than that to which the recipients of support could be eligible under normal conditions) is the creation of artificial conditions for obtaining support. Despite the complexity of this infringement and damage caused by it, until November 2014, there was no legal regulation in Lithuania defining the criteria on the basis of which the creation of artificial conditions could be identified. The Methodology for Identifying Possibly Unlawful Conditions Required for Obtaining Support was approved only by Order No 3D-889 of the Minister of Agriculture of 27 November 2014; it applies to the administration of support under the measures of the Lithuania Rural Development Programme for 2014-2020. On 24 March 2015, the Methodology for Identifying Artificially Created Conditions to Obtain Support during 2007-2013 Programming Period was approved. Both legal acts (the aforementioned Methodologies) establish criteria on the basis of which it can be recognised that artificial conditions have been created to obtain support. Prior to the approval of these Methodologies the possible creation of artificial conditions was investigated in observance of Commission Regulation (EU) No 65/2011 of 27 January 2011, Article 4(8) of which contains the abstract provision that the sanction of recovery of support shall apply for the artificially created conditions. Also, the Judgement of the 
European Court of Justice of 12 September 2013 in Case No C-434/12 explaining the objective and subjective criteria for the creation of artificial conditions was invoked. The investigation of infringements involves the problem of determining the objective criterion on the basis of which the beneficiary's fault and aim to obtain larger support must be disclosed. Still, given the existing obvious aspects (the date of incorporation of beneficiaries, the same shareholders, management, project implementation site, the same activities, mutual transactions, and the same suppliers) it was established that artificial conditions required to obtain support have been created. The Court recognised that the imposition of the sanction - the recovery of support was properly and reasonably imposed on beneficiaries (Vilnius Regional Administrative Court's Judgement of 3 June 2016; Klaipeda Regional Administrative Court's Judgement of 19 September 2016). Often, when assessing other infringements in the case of which the creation or artificial conditions for obtaining support is suspected, there is a lack of evidence for establishing the subjective and objective criteria. Given that the methodology establishing stricter sanctions was approved only on 24 March 2015, it cannot be applied to infringements committed when implementing the measures of the Rural Development Programme for 2007-2013. Under such circumstances it is likely that the gaps in the national legal regulation could have affected the identification of infringements regarding the creation of artificial conditions for obtaining support.

On the other hand, it should be mentioned that the Methodologies approved on 27 November 2014 and 24 March 2015 establish particularly detailed criteria. For the identification of the infringement and recovery of support it is enough when three criteria (of two companies) correspond. These criteria include: the same suppliers of companies (sometimes for acquiring exceptional equipment there may be only one supplier in Lithuania), not only the same shareholders of legal persons, but also the same director, the territory of activities, the incorporation date of companies, etc. No exceptions apply with respect to the incorporation date of companies, although under certain measures support is granted exclusively to the newly established companies. The question is whether the rights of beneficiaries will not be violated due to such legal regulation. The support must be recovered when only three common criteria are identified. It is doubtful whether in such cases damage will not be made to beneficiaries and the recovery of support will not be required from the State. Yet, no case law in this area has been found; however, it is obvious that certain provisions of the Methodology might not work and might limit the right of potential beneficiaries to receive support, and, accordingly, it should be revised.

Gaps in the national regulation can also be found in other legal acts. For instance, subitem 10.4.3.3 of the Implementation Rules (the Implementation Rules approved by Order No 3D-15 of the Minister of Agriculture of the Republic of Lithuania of 6 April 2007) stipulates that the maximum amount of the annual payment to the holding's owner is LTL 150 000. A farm cannot be divided in order to avoid restrictions on aid (LTL 150000 per holding). The maximum amount of the annual payment to the holding's owner established under applicable provisions of subitem 24.2.1 of the Implementation Rules (updated version of 26 February 2016) is EUR 115 848. Therefore, the Implementation Rules also prohibit dividing agricultural holdings in order to receive larger amounts of support. There have been situations in the case law when beneficiaries did not divide their farms (holdings), but (the same entities) purchased new holdings every year and this way received larger support. On one hand, in this case there is no violation of the Implementation Rules because the holdings were not divided. On the other hand, support was received by the same entities benefiting from the fact that the Implementation Rules did not prohibit acquiring new holdings. This also constitutes a regulatory gap. The question arises whether to apply the provisions of Commission Regulation (EU) No 65/2011 of 27 January 2011 which require imposing sanctions for the creation of artificial conditions (although no infringements have been identified during several years) or to act in observance of national legal acts. Given that the EU regulations are directly applicable legal acts, in the event of absence of the national rules of law the provisions of the EU Regulation should be applied. However, without detailed legal regulation and without defined criteria of the artificial conditions the problems of identification and imposition of sanctions for creation of artificial conditions arise. In this regard, we ought to agree with Sanders (2013), who maintains that a lack of coordinated legal regulation between Member States leaves possibility or the interpretation of the rules of law and imposition of different sanctions on Member States for the same infringements. It is, therefore, important not only to improve the national legal regulation, but also to have clearer and more detailed statutory rules of the EU establishing the criteria of infringements according to which sanctions could be imposed. The implementation of legal acts of the EU is a complex process and not all Member States achieve that (Carlier et al. 2010). In supplementing the ideas of the latter scientists it might be worth considering closer cooperation and sharing best practices between countries in order to ensure consistent implementation of the EU legislation.

\section{Certain practical problems in the identification of infringements}

The NPA is required to pay out support funds only after evaluating a payment claim and determining that there are no infringements. If an infringement exists, its nature is assessed and the amount of support is reduced or completely refused. In this regard the issues related to the duration of the evaluation of payment claims arise. Payment claims must be evaluated within 20 working days (the Administration Rules 2007, 2014). The Table below contains the data of 2015 and 2016 confirming the duration of the evaluation of payment claims. The data provided for 2015 are related to the evaluation of 30 cases and for $2016-20$ cases, because of the reduced number of infringements. 
The data presented in the table show that the evaluation of payment claims when the infringement is suspected lasts longer than 20 working days. Protracted evaluation and attempt to identify infringements negatively affects the activities of beneficiaries (often business entities). In practice there are cases when beneficiaries are forced to suspend the implementation of the project because of the lack of resources, accounts are seized and the risk of initiation of bankruptcy proceedings arises. One of the cases which can be mentioned here is when the investigation of infringements in order to find out whether artificial conditions for obtaining support have been created and whether legal acts were violated, took longer than 7 months. During that time, the payment of the remaining amount of support was suspended and due to that the accounts of one of the companies were seized (this is confirmed by the arrest warrant). Having identified no infringements and having decided not to impose any sanctions, support was paid out. However, the business entity had to wait for 7 months and this affected the entity's activities. Other beneficiaries the investigation of whose claims lasts too long are also exposed to unfavourable conditions in respect of their business. On the other hand, the institution administering support must examine all circumstances, collect evidence (e.g., invoices, documentary proof of relationships of shareholders and directors, contracts with suppliers, etc.) in order to objectively assess whether the infringement was committed. The amount of support should be paid out only when it is established that there are no infringements. Otherwise the EU and national budgets can be prejudiced. This confirms the significance of the proper and effective investigation and the identification of infringements and adoption of the decision both for the beneficiaries (business entities) and the EU and the State.

Table 3. Duration of the evaluation of payment claims in months (in the case of evaluation carried out suspecting the infringement in respect of which the proposed sanction is larger than EUR 28 962.00. Data expressed in percent) (Source: the table was drawn up by the author)

\begin{tabular}{c|c|c}
\hline $\begin{array}{c}\text { Duration of evaluation } \\
\text { (NPA, before referring to the Ministry) }\end{array}$ & $\begin{array}{c}2015 \\
\text { (payment claims in \% after } \\
\text { evaluation of 30 cases) }\end{array}$ & $\begin{array}{c}2016 \\
\text { (payment claims in \% } \\
\text { after evaluation of 20 cases) }\end{array}$ \\
\hline Up to 1 month & $0 \%$ & $0 \%$ \\
\hline From 1 to 3 months & $13.3 \%$ & $5 \%$ \\
\hline From 3 to 6 months & $26.7 \%$ & $40 \%$ \\
\hline Over 6 months & $60 \%$ & $55 \%$ \\
\hline
\end{tabular}

Another problem in the identification of infringements is related to the assessment of expert conclusions. National legal acts regulating the administration of the EU support (the Administration Rules 2007: 5.10; the Administration Rules 2014: 10.10) provide that if any suspicions arise regarding the application of higher prices for the construction of a new construction works, reconstruction and overhaul, unreasonably high prices of purchased goods and services or novelty of machinery/equipment - the expert examination of calculated prices or of the novelty and/or depreciation of machinery/equipment shall be carried out. On the basis of the expert examination results, the final decision is adopted regarding eligible expenditure by determining the amount and eligibility of support. By virtue of legislative provision the NPA has the right to involve experts and to determine whether the works, services and goods for which support is sought were carried out and purchased, whether they correspond to market prices, whether the prices are not increased in order to obtain support.

In practice, when the NPA suspects that investments, for which support is sought, were acquired at higher prices, the NPA involves experts in order to determine whether the price of investments corresponds to market prices. If it is found that the price of investments does not correspond to market prices, the beneficiary is informed that the part of support above market prices is not paid out. In that case, the beneficiary disagrees and produces conclusions of experts hired by him. The conclusions issued by the beneficiaries' experts completely differ from those of the NPA's experts (this is reflected in the Judgement of Vilnius Regional Administrative Court of 8 December 2016). The issue of the proper (correct) and effective decision on the granting of support arises. Obtaining expert conclusions, firstly, those of the NPA and then - of the beneficiary, takes time. On the other hand, when the conclusions are completely different, it's unclear which conclusion should be relied upon. Entities of public administration (the NPA, the Ministry) deliberate the matter for several times. The NPA, as a rule, does not change its position and adopts decisions to refuse a part of support on the basis of conclusions of its experts, and the dispute, therefore, reaches the court. The court adjudicating the dispute has the right to assess the experts' conclusions, the experts issuing them, the consistency of conclusions, etc. Once experts are involved, the issue of granting, reduction or refusal of support in the entities administrating support alone can take more than half a year. The Table below contains the data related to the duration of obtaining experts' conclusions, the evaluation and decision-making in the entities of public administration. 
Table 4. Duration of obtaining experts' conclusions and of the investigation after their receipt

(Source: the table was drawn up by the author)

\begin{tabular}{l|c|c}
\hline \multicolumn{1}{c|}{ Year } & 2015 & 2016 \\
\hline Period of receiving expert conclusions ordered by institutions & from 2 weeks to 4 months & from 1.5 week to 5 months \\
\hline $\begin{array}{l}\text { Period investigation by institutions after receiving expert } \\
\text { conclusions }\end{array}$ & from 3 to 9 months & from 3 to 7 months \\
\hline
\end{tabular}

On one hand, conclusions of experts are needed in order to determine the correct amount of support and to avoid damage to the EU and national budgets. On the other hand, a long-lasting process, in particular where the dispute is resolved in favour of the beneficiary (business entity) can cause damage to the beneficiary (business entity). Prolonged granting of support can lead to the halting of investments (e.g., equipment, machinery), activity and its development, etc. The reason for that can be both unfair behaviour of beneficiaries (seeking to obtain without valid grounds a larger amount of support) and lack of impartiality and professionalism on the part of experts. Still, when it is established that the indicated price of investments is abnormally high, a part of support is refused. This means that the remaining part of support is paid out, but its payment is delayed which can negatively affect business entities.

When identifying infringements the issues related to the evaluation of public procurement arise. Given the limited scope of the study, only the issue pertaining to the change of the decision adopted by the entity of public administration by which the public procurement is evaluated will be elaborated here.

In observance of legal acts, prior to disbursing support, the NPA also assesses whether the public procurement was carried out in a proper manner (when public procurement was required). In some cases, after determining that public procurement was carried out by the applicant in a proper manner, the NPA adopts a decision that there were no infringements. Later, after a few years, the NPA notices that the same procurement was conducted in violation of legal acts and, accordingly, decides to apply sanctions. In accordance with legal regulation (Article 3(11) and Article 36 of Law of the Republic of Lithuania on Public Administration) and the case law (Ruling of 2 February 2005 and Decision of 16 March 2012 of the Supreme Administrative Court of Lithuania), an entity of public administration cannot change the decision already passed by it on a certain issue (the consistency, due care and trust in public authorities must be maintained). On the other hand, the Constitutional Court of the Republic of Lithuania (Ruling of the Constitutional Court of the Republic of Lithuania of 14 March 2006) has held that the principle of the rule of law implies that no one can benefit from committed legal offence under the rule of law. Consequences of the violations of law may not be legalised on any grounds and under any circumstances by decisions adopted later by any institutions or officials. A situation occurs when an infringement is identified, but no sanction can be imposed. On the other hand, is the sanctioning for committed infringements really impossible, since the absence of law, after all, cannot give rise to law? However, if infringements were identified by first decision (which has not been done), the beneficiary could have eliminated them and there would have been no threat of recovery of support. The question is about the likely infringement of the beneficiary's rights. The disbursed support is already used, investments already made and activities are being carried out. So in such a case should the violation of established public procurement procedures committed several years ago but unnoticed by the administrative entity entail the recovery of support? It must be regarded that entities of public administration should assume responsibility for the failure to identify the infringement in a timely manner when examining public procurement for the first time. In that case support would not be disbursed, the business entity would have a possibility to rectify the mistakes or take different decisions regarding its activities. The recovery of support after several years in many cases can lead to serious problems for the company (given large amounts of recovered support, see Table 2). In this case, there is an obvious problem of timeliness and effectiveness of identification of the infringement (this must be done in a timely manner, but not several years later). Accordingly, support should be recovered only after establishing an offence which has lead to unjust enrichment, misappropriation of funds, etc. The latter issue is only named in this article, but its disclosure and solutions could be a subject of a separate study.

\section{Conclusions}

The EU financial support for rural development should help in achieving the objectives of the agricultural policy. To that end funds under various measures of the Rural Development Programme for Lithuania are allocated to business entities, farmers. Information on the granting and disbursement of funds and amounts of sanctions shows that the identification of infringements is a relevant and important process of administration and control of the EU financial support for rural development during which violations of legal acts are identified and sanctions are imposed (full or partial recovery of support). This way the achievement of the proper implementation of the EU and national budget funds is sought in order not to prejudice the EU and national budgets.

Regulatory gaps and inadequate restriction of access to or consumption of support can be detrimental to both the EU and national budgets and the beneficiaries. Legal acts setting the criteria regarding the creation of artificial conditions for obtaining support should be revised and amended, because certain criteria are not justified and not 
harmonised with other legal acts and, therefore, can unreasonably limit the possibilities of access to financial support and the implementation of projects.

Evaluation of payment claims, obtaining and assessing conclusions of experts is necessary in order to ensure proper use of support and can be of different duration depending on circumstances. Nevertheless, the assessment of documents which predetermines the adoption of decisions on payment (refusal) of support, should be not only appropriate, but also effective and timely, so as to ensure both public (EU, State) and private (business, other beneficiaries) interests.

\section{References}

Baležentis, A.; Baležentis, T. 2010. Evaluation of sustainable rural development in the European Union member states, Management Theory and Studies for Rural Business and Infrastructure Development 23(4): 1-9.

Carlier, L.; Rotar, I.; Vidican, R. 2010. The EU policy regulates and controls the farming practices, Agriculture 67(1): 1-11.

Commission Regulation (EU) No 1848/2006 of 14 December 2006 concerning irregularities and the recovery of sums wrongly paid in connection with the financing of the common agricultural policy and the organisation of an information system in this field and repealing Council Regulation (EEC) No 595/91 (OJ 2006 L 355, p. 56).

Commission Regulation (EU) No 65/2011 of 27 January 2011 laying down detailed rules for the implementation of Council Regulation (EC) No 1698/2005, as regards the implementation of control procedures as well as cross-compliance in respect of rural development support measures (OJ 2011 L 25, p. 8).

Damulienè, A. 2012. EU financial support for rural tourism, Studies of Social Sciences 4(1): 125-138.

Jakaitienè, A.; Klyvienė, V. 2007. Effects of the EU financial support on the economic development of Lithuania, Monetary Studies. Theory and Practice of Economics 2: 24-46.

Judgement of Klaipeda Regional Administrative Court of 19 September 2016 in Administrative Case No eI-2645-386/2016.

Judgement of the Constitutional Court of the Republic of Lithuania of 14 March 2006 in case No 17/02-24/02-06/03-22/04.

Judgement of the European Court of Justice of 12 September 2013 in the Case No C-434/12 [online], [cited 24 January 2017]. Available from Internet: http://curia.europa.eu

Judgement of the Supreme Administrative Court of Lithuania of 16 March 2012 in Administrative Case No I02-6/2012).

Judgement of the Supreme Administrative Court of Lithuania of 2 August 2016 in Administrative Case No A-2617-575/2016.

Judgement of the Supreme Administrative Court of Lithuania of 4 February 2005 in Administrative Case No A ${ }^{2}-161 / 2005$.

Judgement of Vilnius Regional Administrative Court of 3 June 2016 in Administrative Case No eI-4266-142/2016.

Judgement of Vilnius Regional Administrative Court of 8 December 2016 in Administrative Case No I-6890-189/2016.

Kelsen, H. 2002. Pure theory of law. Vilnius: Eugrimas.

Law of the Republic of Lithuania on Public Administration. 1999, No 60-1945 (updated version).

Lobanova, L. 2015. Human Resources Management within the Context of Cohesion Processes of the European Union: Doctoral Dissertation. Social Sciences, Management (03S). Vilnius Gediminas Technical University.

Massot, A. 2016. The Common Agricultural Policy (CAP) and the Treaty [online], [cited 22 January 2017]. Available from Internet: http://www.europarl.europa.eu/atyourservice/lt/displayFtu.html?ftuId=FTU_5.2.1.html

Melnikas, B. 2012a. Cohesion and uniqueness: new challenges in the environment of globalisation, internationalisation and European integration processes, Theoretical and Practical Magazine. Public Administration 1(33): 31-46.

Melnikas, B. 2012b. Cohesion processes in the European Union: tendencies and new challenges, European Integration Studies: Research and Topicalities 6: 150-159. https://doi.org/10.5755/j01.eis.0.6.1705

Melnikas, B. 2012c. Regionalization processes under globalisation conditions: model of "orbits" and improvement of operating efficiency in business and public sector, Regional Formation and Development Studies 2(10).

Methodology for Identifying Artificially Created Conditions to Obtain Support during 2007-2013 Programming Period approved by Order No 3D-213 of the Minister of Agriculture of the Republic of Lithuania of 24 March 2015.

Methodology for Identifying Possibly Unlawful Conditions Required for Obtaining Support approved by Order No 3D-889 of the Minister of Agriculture of the Republic of Lithuania of 27 November 2014.

Muiznieks. N.; Rozenvalds, J.; Birka, I. 2013. Ethnicity and social cohesion in the post-Soviet Baltic States, Patterns of Prejudice 47(3): 288-308. https://doi.org/10.1080/0031322X.2013.812349

Opinion of the European Economic and Social Committee "The role and priorities of cohesion policy within the EU 2020 strategy". 2011/C 248/01. Exploratory Opinion to the EU Council [online], [cited 28 December 2016]. Available from Internet: http://eurlex.europa.eu/LexUriServ/LexUriServ.do?uri=OJ:C:2011:248:0001:0007:LT:PDF

Palšova, L.; Schwarczova, L.; Schwarcza, P.; Bandlerova, A. 2014. The support of implementation of organic farming in the Slovak Republic in the context of sustainable development, Procedia - Social and Behavioral Sciences 110: 520-529. https://doi.org/10.1016/j.sbspro.2013.12.896

Panorama. 2014-2020 Cohesion Policy. Winter 2013 No 48 [online], [cited 28 December 2016]. Available from Internet: http://ec.europa.eu/regional_policy/sources/docgener/panorama/pdf/mag48/mag48_lt.pdf

Potluka, O. [et al.]. 2010. Impact of EU Cohesion Policy in Central Europe. Leipziger Universitätsverlag [online], [cited 28 December 2016]. Available from Internet: http://km.vse.cz/wp-content/uploads/2011/06/Impact-of-EU-Cohesion-Policy-inCentral-Europe-print-www.pdf

Rakauskienè, O. G.; Ivashinenko, N. 2011. The economic and social cohesion of EU: methodology of investigation, Intellectual Economics 54(12): 575-589. 
Rules for the administration of the Lithuanian Rural Development Programme for 2007-2013 approved by Order No 3D-153 of the Minister of Agriculture of the Republic of Lithuania of 6 April 2007.

Rules for the administration of the Lithuanian Rural Development Programme for 2014-2020 by Order No 3D-507 of the Minister of Agriculture of the Republic of Lithuania of 26 August 2014.

Rules for the administration of violations of legislative provisions related to the implementation of measures of European Agricultural Guarantee Fund, the European Agricultural Fund for Rural Development and the European Fisheries Fund approved by Order No 3D-80 of the Minister of Agriculture of the Republic of Lithuania of 5 February 2010.

Rules for the implementation of the programmes "Landscape management", "Organic farming" and "Improving conditions in the water entities at risk" under the measure "Agri-environment payments" of the Lithuanian Rural Development Programme for 2007-2013 approved by Order No 3D-152 of the Minister of Agriculture of the Republic of Lithuania of 6 April 2007.

Sanders, J. (Ed.) 2013. Evaluation of the EU legislation on organic farming. Germany, Braunschweig: Thünen Institute of Farm Economics.

Statistics on the implementation of the Lithuanian Rural Development Programme for 2014-2020. 2014-2016 Data of the National Paying Agency under the Ministry of Agriculture [online], [cited 12 December 2016]. Available from Internet: https://www.nma.lt/index.php/parama/lietuvos-kaimo-pletros-20142020-m-programa/statistika/9156\#res

Taran, P.; Ivarhnyuk, I.; da Conceicao Pereira Ramos, M.; Tanner, A. 2010. Economic migration, social cohesion and development: towards an integrated approach. Council of Europe Publishing [online], [cited 28 December 2016]. Available from Internet: http://www.coe.int/t/dg3/migration/archives/documentation/Migration\%20management/2008_Migration\%20thematic\%20re port_en.pdf.

The arrest warrant retained by the Ministry of Agriculture of the Republic of Lithuania. 2016, No 3.23.

Thomson, R.; Torenvlied, R.; Arregui, J. 2007. The paradox of compliance: infringements and delays in transposing European

Union Directives, British Journal of Political Science 37(4): 685-709. https://doi.org/10.1017/S0007123407000373

Vaišvila, A. 2004. Legal theory. Vilnius: Justitia.

Van Well, L. 2012. Conceptualizing the logics of territorial cohesion, European Planning Studies 20(9): 1549-1567. https://doi.org/10.1080/09654313.2012.708021

Vaznonis, V.; Vaznonis, B. 2011. Common agricultural policy prospects: towards sustainable development, Management Theory and Studies for Rural Business and Infrastructure Development 1(25): 231-236.

Wiener, A.; Diez, Th. 2009. European integration theory. Oxford: Oxford University Press. 